\title{
Perlindungan Hukum Pidana Terhadap Nasabah Dalam Pelaksanaan Pinjam Meminjam Uang Berbasis Teknologi Informasi (Fintech) Peer To Peer Lending
}

\author{
Siti Nasikhatuddini \\ Magister Hukum Fakultas Hukum Universitas Islam Indonesia Yogyakarta Indonesia \\ Jln. Cik Di Tiro No. 1 Yogyakarta Indonesia \\ 19912071@students.uii.ac.id
}

\begin{abstract}
In the digital era, technological developments are increasingly rapid, and their existence has begun to penetrate into various aspects of life, such as in the world of finance or the economy. This is marked by the emergence of technology and information-based financial institutions or known as fintech. Starting from this, a question arises on how to implement information technology-based lending and borrowing (peer to peer lending) in Indonesia and how to protect the recipients of the loan (customers). This research is in the form of juridical-normative. The results of this study concluded that there were violations committed by the lender to the customer, and the sanctions imposed were only administrative sanctions with the worst consequence being license revocation. In this regards, obviously it does not provide a sense of justice to the customers, considering the crimes that have been committed, therefore the role of criminal law is very important here, by implementing sanctions related to these crimes, such as the dissemination of personal data, threats in billing, sexual harassment through electronic media, fraud and slander.
\end{abstract}

Key Words: Fintech; peer to peer lending; protection of customers

\begin{abstract}
Abstrak
Era digital perkembangan teknologi kian pesat, dan keberadaanya pun mulai merambah ke berbagai aspek kehidupan, seperti halnya dalam dunia keuangan atau ekonomi. Hal ini ditandai dengan munculnya lembaga keuangan berbasis teknologi dan informasi atau dikenal dengan fintech. Bermula dari hal tersebut timbul suatu pertanyaan mengenai bagaimana pelaksanaan pijam meminjam berbasis teknologi informasi (peer to peer lending) di Indonesia dan bagaimana perlindungan terhadap penerima pinjaman (nasabah). Penelitian ini berbentuk yuridis-normatif. Hasil penelitian ini menyimpulkan bahwa terjadi pelanggaran yang dilakukan pemberi pinjaman kepada penerima pinjaman (nasabah), dan sanksi yang dijatuhkan hanya sebatas sanksi administratif dengan konsekuensi terparahnya yaitu pencabutan izin. Mengenai hal tersebut tentu saja tidak memberikan rasa keadilan terhadap nasabah, mengingat tindak kejahatan yang sudah dilakukan, oleh sebab itu peran hukum pidana sangat penting di sini, dengan cara menerapkan sanksi-sanksi yang berkaitan dengan kejahatan tersebut, seperti penyebaran data pribadi, pengancaman dalam penagihan, pelecehan seksual melalui media elektronik, penipuan dan fitnah.
\end{abstract}

Kata-kata Kunci : Fintech; peer to peer lending; perlindungan terhadap nasabah 


\section{Pendahuluan}

Era digital membuat banyak perubahan di berbagai sektor kehidupan, tidak terkecuali sektor perbankan. Bank merupakan lembaga keuangan yang berperan penting dalam sistem pengelolaan keuangan negara dan pemerataan ekonomi. Perkembangan teknologi menuntut lembaga perbankan berinovasi dengan menciptakan sistem perbankan berbasis teknologi yang dikenal dengan fintech (financial technology) atau teknologi keuangan. ${ }^{1}$ Secara sederhana fintech dapat diartikan sebagai pemanfaatan teknologi informasi untuk meningkatkan layanan di industri keuangan. ${ }^{2}$ Fintech biasanya didirikan oleh perusahaan perintis untuk mempermudah bidang layanan keuangan dengan memanfaatkan teknologi dengan berbagai kemudahan yang ditawarkan seperti efisiensi waktu, biaya, kecepatan dan keamanan.

Otoritas Jasa Keuangan (OJK) mengeluarkan aturan No.77/POJK.01/2016 tentang Layanan Pinjam Meminjam Uang Berbasis Teknologi Informasi untuk mengatur penyelenggaraan peer to peer lending. Dalam pelaksanaanya kegiatan ini melibatkan tiga pihak yaitu penyelenggara, penerima pinjaman dan pemberi pinjaman. ${ }^{3}$ Penyelenggara adalah badan hukum Indonesia yang menyediakan, mengelola, dan mengoperasikan Layanan Pinjam Meminjam Uang Berbasis Teknologi Informasi. Penerima Pinjaman adalah orang dan/atau badan hukum yang mempunyai utang karena perjanjian Layanan Pinjam Meminjam Uang Berbasis Teknologi Informasi. Pemberi Pinjaman adalah orang, badan hukum, dan/atau badan usaha yang mempunyai piutang karena perjanjian Layanan Pinjam Meminjam Uang Berbasis Teknologi Informasi."4

Seiring dengan memburuknya perekonomian nasional pada masa pendemi Covid 19, pinjaman berbasis fintech semakin ramai digunakan. Hal ini disebabkan prosesnya lebih mudah dibanding pada saat melakukan pinjaman ke Bank.

Selain Otoritas Jasa Keuangan, Bank Indonesia juga mengeluarkan Peraturan BI Nomor 19/12/PBI/2017 tentang Penyelenggaraan Teknologi Finansial, dalam peraturan tersebut Bank Indonesia mengatur kewajiban pendaftaran bagi penyelenggara teknologi finansial yang melakukan kegiatan khusus pada sistem pembayaran. Kewajiban pendaftaran tersebut dikecualikan bagi penyelenggara jasa sistem pembayaran yang telah memperoleh izin dari

\footnotetext{
${ }^{1}$ Irma Muzdalifa, Inayah Aulia Rahma, dan Bela Gita Novalia, "Peran Fintech Dalam Meningkatkan Keuangan Inklusif Pada UMKM Di Indonesia (Pendekatan Keuangan Syariah)", artikel dalam Jurnal Masharif AlSyariah : Jurnal Ekonomi dan Perbankan Syariah, Vol.3, No.1, (2018), hlm. 6.

2 Otoritas Jasa Keuangan, Kajian Perlindungan Konsumen Sektor Jasa Kenangan: Perlindungan Konsumen Pada Fintech, Departemen Perlindungan Konsumen OJK,(Jakarta, 2017), hlm. 8.

3 Peraturan OJK Nomor 77/ POJK.01/ 2016 tentang Layanan Pinjam Meminjam Uang Berbasis Teknologi Informasi, Pasal 1 angka 3.

${ }^{4}$ Ibid., Pasal 1 angka 6-8.
} 
Bank Indonesia dan bagi penyelenggara teknologi finansial yang berada di bawah kewenangan otoritas lain. Keseriusan Bank Indonesia dibuktikan dengan dibentuknya divisi khusus yang disebut dengan Bank Indonesia Fintech Office yang bertujuan untuk memfasilitasi perkembangan teknologi dalam sistem keuangan di Indonesia. Dengan dibuatnya divisi tersebut pelaksanaan mengenai pinjam meminjam uang berbasis peer to peer lending diharapkan dapat berjalan dengan baik dan tidak ada pihak yang dirugikan.

Pada kenyataanya pelaksanaan pinjam meminjam uang tersebut mengalami berbagai permasalahan. Permasalahan yang sering terjadi seperti pelanggaran cyber criminal dengan berbagai macam jenisnya.

\section{Rumusan Masalah}

Berdasarkan latar belakang di atas dapat dirumuskan permasalahan berikut, pertama, bagaimana pelaksanaan pinjam meminjam uang berbasis teknologi dan informasi peer to peer lending di Indonesia? Kedua, bagaimana perlindungan hukum pidana terhadap penerima pinjaman?

\section{Tujuan Penelitian}

Penelitian ini memiliki tujuan-tujuan sebagai berikut, pertama, Untuk mengkaji pelaksanaan pinjam meminjam uang berbasis teknologi dan informasi peer to peer lending di Indonesia. Kedua, Untuk menganalisis perlindungan hukum pidana terhadap penerima pinjaman.

\section{Metode Penelitian}

Jenis penelitian ini masuk ke dalam kategori yuridis-normatif yaitu penelitian yang dilakukan dengan cara menelaah teori-teori, konsep-kosep, asas hukum dan peraturan perundang-undangan yang sesuai dan berkaitan dengan objek penelitian. Penelitian ini menggunakan metode library research yaitu penelitian yang dilakukan dengan menggunakan literatur kepustakaan, baik menggunakan buku, jurnal ilmiah, website internet dan referensi lain yang relevan. Data yang diperoleh diolah secara kualitatif dan disajikan dalam bentuk deskriptif, yaitu dengan maksud untuk memberikan data yang seteliti mungkin mengenai permasalahan yang dibahas dalam penelitian ini.

\section{Hasil Penelitian dan Pembahasan}

\section{Pelaksanaan Fintech (Financial Technology) Peer to Peer Lending di Indonesia}

Perkembangan fintech merupakan momentum global yang terjadi di seluruh dunia termasuk Indonesia. Teknologi ini diperkirakan akan masuk menjadi salah 
satu pasar ekonomi digital terbesar di Asia Tenggara pada 2025 dengan kelompok masyarakat berpenghasilan menengah (middle income) yang terus tumbuh. Fintech adalah variasi model bisnis dan perkembangan teknologi untuk meningkatkan layanan industri keuangan ${ }^{5}$. Selain itu fintech juga diartikan sebagai suatu teknologi yang menjadi perantara dan penghubung masyarakat umum dengan sektor jasa keuangan dan jasa finansial. ${ }^{6}$ Bank Indonesia menyebutkan bahwa fintech memberikan peranan dalam membantu transaksi jual beli agar lebih praktis, dengan fungsinya adalah sebagai katalisator untuk pertukaran ide inovatif, bussines intelegence, assesment, dan fungsi koordinasi. ${ }^{7}$

Di Indonesia fintech terdiri dari beberapa jenis yaitu digital payment dan financing and invesment. Digital payment merupakan layanan berupa transaksi online, sedangkan financing and invesment adalah suatu bentuk perusahaan fintech yang memberikan layanan crowfunding yang pada umumnya melakukan penghimpunan dana untuk pembiayaan suatu proyek event maupun kegiatan sosial. ${ }^{8}$ Selain itu, ada beberapa jenis fintech lain yang ada di Indonesia seperti account agregator, information and feeder site dan personal finance. ${ }^{9}$

Di Indonesia fintech jenis lending banyak diminati karena memiliki banyak kemudahan seperti tanpa harus memiliki agunan atau jaminan. Dari kesemua jenis lending yang paling terkenal yaitu peer to peer lending. Jenis fintech peer to peer lending dikenal pertama kali di Britania Raya melalui perusahaan Zopa pada 2005, yang kemudian diikuti oleh Amerika Serikat ${ }^{10}$. Wadah ini dikenal sebagai suatu platfrom yang dijadikan wadah saling bertemunya pemberi pinjaman dan penerima pinjaman untuk melakukan transaksi pinjam meminjam uang secara online. Target utama dari fintech peer to peer lending yaitu kalangan menengah kebawah yang kekurangan modal untuk mengambangkan dan mempertahankan usahanya, terutama dimasa pendemi Covid 19.11 Selain pengusaha kecil, target dari fintech ini juga meliputi orang yang menggunakannya sebagai kredit konsumtif karena kesulitan memenuhi kebutuhan hidup sehari-hari.

${ }^{5}$ Ibid., hlm. 8.

${ }^{6}$ Arif Syaifudin "Perlindungan Hukum Terhadap Para Pibak Didalam Layanan Financial Technologi Berbasis Peer to Peer (P2P) Lending", artikel dalam Dinamika Jurnal Ilmiah Ilmu Hukum, Vol. 26 Nomor 4, Februari (2020), hlm. 409.

${ }^{7}$ Asna Ridayani "Perlindungan Hukum Bagi Pengguna Jasa Peer To Peer Lending Terhadap Ketrerlambatan Pembayaran Pinjaman Dalam Finansial Teknologi”, (Skripi Fakultas Hukum Universitas Jember, 2019), hlm. 1819.

${ }^{8}$ Otoritas Jasa Keuangan, Op. Cit., hlm. 28.

9 Astri Rumondang dkk, Fintech: Inovasi Sistem Keuangan Di Era Digital, Yayasan Kita Menulis, Medan 2019, hlm. 13-17.

10 Ratna Hartanto dan Juliani Purnama Ramli, "Hubungan Hukum Para Pihak Dalam Peer To Peer Lending”, artikel dalam Jurnal Hukum IUS Quia Iustum Faculty Of Law UII, Vol.25, Issue 2, Mei (2018), hlm. 2.

${ }^{11}$ https://www.cnbcindonesia.com/tech/20191014113024-37-106736/berkat-fintech-lending-sederetumkm-ini-bisa-naik-kelas, diakses pada 25 Agustus 2021. 
Pemilik platfrom atau aplikasi memiliki andil dan wewenang yang besar dalam pinjam meminjam berbasis elektronik. Hal ini karena pemilik platform merupakan pihak yang menginvestasikan uang untuk dikelola oleh penyelenggara sebagai pinjaman bagi pihak yang membutuhkan. Perjanjian dalam hal ini dibagi menjadi dua bagian, yaitu perjanjian antara pemberi pinjaman dengan penyelenggara dan perjanjian antara pemberi pinjaman dan penerima pinjaman. Perihal tersebut tertuang dalam Pasal 1 angka 12 Peraturan OJK Nomor 77/POJK.01/2016 tentang Layanan Pinjam Meminjam Uang Berbasis Teknologi Informasi, yang menyebutkan bahwa:

"Dokumen elektronik adalah setiap informasi yang dibuat, diteruskan, dikirimkan, diterima, atau disimpan dalam bentuk analog, digital elektromagnetik, optikal atau sejenisnya yang dapat dilihat, ditampilkan, dan/atau didengar melalui komputer atau sistem elektronik termasuk tetapi tidak terbatas pada tulisan,suara,gambar,peta rancangan, foto atau sejenisnya, huruf, tanda angka, kode, akses, simbol atau perforasi,yang memiliki makna atau arti dapat difahami, oleh orang yang mampu memahaminya sebagaimana dimaksud dalam Undang-Undang Nomor 11 tahun 2008 tentang Informasi dan Transaksi Elektronik."12

Perjanjian antara penyelenggara dan pemberi pinjaman sebagaimana diatur dalam Pasal 19 ayat (2) Peraturan OJK Nomor 77/POJK.01/2016 paling sedikit harus memuat:
a. Nomor perjanjian
b. Tanggal perjanjian
c. Identitas para pihak
d. Ketentuan mengenai hak dan kewajiban para pihak
e. Jumlah pinjaman
f. Suku bunga pijaman
g. Besarnya komisi
h. Jangka waktu
i. Objek jaminan (jika ada)
j. Rincian biaya terkait
k. Ketentuan mengenai denda (jika ada)
1. Mekanisme penyelesaian sengketa. ${ }^{13}$

Dalam ketentuan Pasal 20 ayat (2) Peraturan OJK Nomor 77/POJK.01/2016 tentang Layanan Pinjam Meminjam Uang Berbasis Teknologi Informasi, dokumen elektronik yang berisi perjanjian antara pemberi pinjaman dengan penerima pinjaman paling sedikit harus memuat:
a. Nomor perjanjian
b. Tanggal perjanjian

${ }_{12}$ Peraturan OJK Nomor 77/POJK.01/2016, Op. Cit., Pasal 1 angka 12.

${ }^{13}$ Ibid., Pasal 19 ayat (2). 

c. Identitas para pihak
d. Ketentuan mengenai hak dan kewajiban para pihak
e. Jumlah pinjaman
f. Suku bunga pinjaman
g. Nilai angsuran
h. Jangka waktu
i. Objek jaminan (jika ada)
j. Rincian biaya terkait
k. Ketentuan mengenai denda jika ada
1. Mekanisme penyelesaian sengketa. ${ }^{14}$

Selain dokumen elektronik, penandatanganan kedua perjanjiannya juga dilakukan secara elektronik, atau dikenal dengan tanda tangan elektronik. Hal ini sebagaimana termaktub dalam Pasal 1 angka 15 Peraturan OJK Nomor 77/POJK.01/2016 tentang Layanan Pinjam Meminjam Uang Berbasis Teknologi Informasi yang menyebutkan bahwa:

"Tanda tangan elektronik adalah tanda tangan yang terdiri atas informasi elektronik yang dilekatkan, terasosiasi atau terikat dengan informasi elektonik lainnya yang digunakan sebagai alat verifikasi dan autentikasi sebagaimana dimaksud dalam UndangUndang Nomor 11 Tahun 2008 tentang Informasi dan Transaksi Elektronik."15

Mengenai pelaksanaan peer to peer lending, calon pengguna akan berperan sebagai pihak pemberi pinjaman, oleh sebab itu ia terlebih dahulu harus mendaftarkan dirinya sebagai pemberi pinjaman, dengan cara menyerahkan dokumen dan data elektronik yang terkait dengan data-data pribadinya seperti nama lengkap, e-mail, nomor handphone, nomor KTP, nomor NPWP (jika memiliki NPWP), nomor rekening bank yang akan digunakan, dan jumlah uang yang akan diinvestasikan atau dipinjamkan. Setelah semua data tersebut diverifikasi oleh penyelenggara, maka akan ada petunjuk persetujuan yang harus disetujui oleh pemberi pinjaman, dimana salah satu persetujuan tersebut yaitu mematuhi setiap aturan-aturan yang ditetapkan oleh penyelenggara termasuk klausul disclaimer.

Selain hal tersebut di atas, pemberi pinjaman juga wajib mematuhi setiap isi perjanjian yang dilakukan antara pemberi pinjaman dengan pihak penyelenggara, dan juga perjanjian antara pemberi pinjaman dengan penerima pinjaman. Pemberi pinjaman yang sudah diverifikasi mendapatkan data-data dari beberapa penerima pinjaman yang sudah terdaftar dan terverifikasi oleh penyelenggara. Selanjutnya, pemberi pinjaman dapat memilih salah satu dari calon penerima pinjaman, jika sudah terjadi kesepakatan maka pemberi pinjaman akan mendapatkan return dari bunga hasil pembayaran angsuran.

\footnotetext{
14 Ibid, Pasal 20 ayat (2).

${ }^{15}$ Ibid, Pasal 1 Angka 15.
} 


\section{Perlindungan Hukum Pidana Terhadap Penerima Pinjaman}

Dalam pelaksanaanya peer to peer lending tidak selalu berjalan mulus seperti yang diharapkan. Seringkali timbul suatu kejahatan-kejahatan yang dilakukan oleh pemberi pinjaman kepada nasabah. Kejahatan-kejahatan yang ada dapat dikelompokkan dan disertakan dengan peraturan hukumnya, yaitu:

\begin{tabular}{|c|c|}
\hline Kejahatan & Aturan Hukum \\
\hline 1. Penyebaran data pribadi & 1. Pasal 32 Jo Pasal 48 UU ITE \\
\hline 2. Pengancaman dan penagihan & 2. Pasal 365 KUHP dan Pasal $29 \mathrm{Jo}$ \\
\hline 3. Pelecehan seksual melalui media & Pasal 45 UU ITE \\
\hline elektronik & 3. Pasal 27 ayat (1) Jo 45 ayat (1) UU \\
\hline 4. Penipuan & ITE \\
\hline 5. Fitnah & 4. Pasal 378 KUHP \\
\hline & 5. Pasal 311 ayat (1) KUHP \\
\hline
\end{tabular}

Bagan tersebut menunjukan perlunya penegakan hukum secara pidana, baik pidana umum yang terdapat dalam KUHP maupun pidana khusus atau diluar KUHP (UU ITE). Hal ini mengingat OJK selama ini baru menerapkan sanksi administratif saja, padahal terdapat sanksi pidana sebagai bentuk perlindungan hukum terhadap nasabah. Isi dan penjelasan pasal tersebut di atas dijabarkan sebagai berikut:

1. Penyebar data pribadi

Hal ini diatur dalam Pasal 32 Juncto Pasal 48 Undang-Undang Nomor 11 Tahun 2008 (UU ITE) yang berbunyi sebagai berikut.

Pasal 32

(1)Setiap Orang dengan sengaja dan tanpa hak atau melawan hukum dengan cara apa pun mengubah, menambah, mengurangi, melakukan transmisi, merusak, menghilangkan, memindahkan, menyembunyikan suatu Informasi Elektronik dan/atau Dokumen Elektronik milik Orang lain atau milik publik.

(2)Setiap Orang dengan sengaja dan tanpa hak atau melawan hukum dengan cara apa pun memindahkan atau mentransfer Informasi Elektronik dan/atau Dokumen Elektronik kepada Sistem Elektronik Orang lain yang tidak berhak.

(3)Terhadap perbuatan sebagaimana dimaksud pada ayat (1) yang mengakibatkan terbukanya suatu Informasi Elektronik dan/atau Dokumen Elektronik yang bersifat rahasia menjadi dapat diakses oleh publik dengan keutuhan data yang tidak sebagaimana mestinya. ${ }^{16}$

Pasal 48

(1)Setiap Orang yang memenuhi unsur sebagaimana dimaksud dalam Pasal 32 ayat (1) dipidana dengan pidana penjara paling lama 8 (delapan) tahun dan/atau denda paling banyak Rp2.000.000.000,00 (dua miliar rupiah).

${ }^{16}$ Undang-Undang Nomor 11 Tahun 2008 tentang Informasi Dan Transaksi Elektronik, Pasal 32. 
(2) Setiap Orang yang memenuhi unsur sebagaimana dimaksud dalam Pasal 32 ayat (2) dipidana dengan pidana penjara paling lama 9 (sembilan) tahun dan/atau denda paling banyak Rp3.000.000.000,00 (tiga miliar rupiah).

(3) Setiap Orang yang memenuhi unsur sebagaimana dimaksud dalam Pasal 32 ayat (3) dipidana dengan pidana penjara paling lama 10 (sepuluh) tahun dan/atau denda paling banyak Rp5.000.000.000,00 (lima miliar rupiah). ${ }^{17}$

Apa yang dicantumkan dalam pasal-pasal tersebut haruslah dilakukan, mengingat data pribadi merupakan hal yang sangat rentan dan krusial. Pada praktek yang terjadi dilapangan data pribadi yang sudah tersebar akan digunakan sebagai alas tindak kejahatan, baik keuangan maupun yang lebih berat. Kejahatan ini berada pada urutan teratas karena identitas pribadi merupakan cikal bakal kejahatan elektronik jika keberadaanya sudah terssebar, dan melakukan kejahatan akan terasa mudah.

2. Pengancaman dalam penagihan, Pasal 365 KUHP dan Pasal 29 KUHP Juncto Pasal 45 Undang-Undang Nomor 11 Tahun 2008 (UU ITE)

\section{Pasal 365 KUHP}

(1)Diancam dengan pidana penjara paling lama sembilan tahun, pencurian yang didahului, disertai atau diikuti dengan kekerasan atau ancaman kekerasan, terhadap orang, dengan maksud untuk mempersiap atau mempermudah pencurian atau dalam hal tertangkap tangan, untuk memungkinkan melarikan diri sendiri atau peserta lainnya, atau untuk tetap menguasai barang yang dicurinya.

(2)Diancam pidana penjara paling lama dua belas tahun.

Ke-1. Jika perbutan dilakukan pada waktu malam dalam rumah atau pekarangan tertutup yang ada rumahnya, dijalan umum, atau dalam kereta api atau trem yang sedang berjalan

Ke-2. Jika perbuatan dilakukan oleh dua orang atau lebih dengan bersekutu.

Ke-3. Jika masuknya ketempat melakukan kejahatan, dengan merusak atau memanjat atau dengan memakai anak kunci palsu, perintah palsu, atau pakaian jabatan palsu.

Ke-4. Jika perbuatan mengakibatkan luka-luka berat.

(3)Jika perbuatan mengakibatkan mati, maka dikenakan pidana penjara paling lama lima belas tahun.

(4)Diancam dengan pidana mati atau pidana penjara seumur hidup atau selama waktu tertentu paling lama dua puluh tahun, jika perbuatan mengakibatkan luka berat atau mati dan dilakukan oleh dua orang atau lebih dengan bersekutu, pula disertai oleh salah satu hal yang diterangkan dalam no.1 dan 3.18

\section{Pasal 29 KUHP}

(1)Hal yang menunjuk tempat untuk menjalani pidana penjara, kurungan,atau kedua-duanya, begitu juga hal mengatur dan mengurus tempat-tempat itu, hal membedakan orang terpidana dalam golongan-golongan, hal mengatur

17 Ibid., Pasal 48.

18 Kitab Undang-Undang Hukum Pidana, Pasal 365. 
pekerjaan, upah pekerjaan, dan perumahan terpidana yang berdiam diluar penjara, hal mengatur pemberian pengajaran, penyelenggaraan ibadat agama, hal tata tertib, hal tempat untuk tidur, hal makan dan pakaian, semuanya itu diatur dengan undang-undang sesuai dengan kitab undang-undang ini.

(2) Jika perlu Menteri Kehakiman menetapkan aturan rumah tangga untuk tempattempat orang terpidana. ${ }^{19}$

Pasal 45 Undang-Undang Nomor 11 Tahun 2008 (UU ITE)

(1)Setiap Orang yang memenuhi unsur sebagaimana dimaksud dalam Pasal 27 ayat (1), ayat (2), ayat (3), atau ayat (4) dipidana dengan pidana penjara paling lama 6 (enam) tahun dan/atau denda paling banyak Rp1.000.000.000,00 (satu miliar rupiah).

(2)Setiap Orang yang memenuhi unsur sebagaimana dimaksud dalam Pasal 28 ayat (1) atau ayat (2) dipidana dengan pidana penjara paling lama 6 (enam) tahun dan/atau denda paling banyak Rp1.000.000.000,00 (satu miliar rupiah).

(3)Setiap Orang yang memenuhi unsur sebagaimana dimaksud dalam Pasal 29 dipidana dengan pidana penjara paling lama 12 (dua belas) tahun dan/atau denda paling banyak Rp2.000.000.000,00 (dua miliar rupiah). ${ }^{20}$

Kejahatan pada kategori ini utamanya yaitu dikenakan pasal pencurian, hal tersebut dikarenakan nasabah sudah membayar tagihan hutang sesuai dengan yang diperjanjikan akan tetapi terjadi rekayasa sistem yang dilakukan oleh pemilik jasa keuangan, sehingga tagihan yang dibayarkan oleh nasabah tidak masuk kedalam sistem, dan secara tidak langsung pemberi pinjaman telah mencuri uang nasabah. Kejadian ini diperparah dengan penagihan yang dilakukan secara implusif, yaitu dengan cara menelefon semua nomor pihak keluarga terhutang yang seyogyanya tidak ada kaitannya dengan transaksi tersebut. Selain itu juga terjadi perampasan beberapa aset yang nilainya melebihi juhmlah hutang (unsur perampasan kental di sini).

3. Pelecehan seksual melalui media elektronik, Pasal 27 ayat (1) Juncto Pasal 45 ayat (1) Undang-Undang Nomor 11 Tahun 2008 (UU ITE)

Pasal 27 ayat (1)

(1)Setiap Orang dengan sengaja dan tanpa hak mendistribusikan dan/atau mentransmisikan dan/atau membuat dapat diaksesnya Informasi Elektronik dan/atau Dokumen Elektronik yang memiliki muatan yang melanggar kesusilaan. ${ }^{21}$

Pasal 45 ayat (1)

(1)Setiap Orang yang memenuhi unsur sebagaimana dimaksud dalam Pasal 27 ayat (1), ayat (2), ayat (3), atau ayat (4) dipidana dengan pidana penjara paling

19 Ibid, Pasal 29.

${ }^{20}$ Op. Cit., Pasal 45.

${ }^{21}$ Ibid, Pasal 27 ayat (1). 
lama 6 (enam) tahun dan/atau denda paling banyak Rp1.000.000.000,00 (satu miliar rupiah). ${ }^{22}$

Pada kategori ini, kejahatan terkait biasanya rentan terjadi kepada nasabah perempuan, yang akan terjadi apabila dianggap tidak dapat memenuhi kewajibannya selaku pihak yang berhutang, dilakukan dengan berbagai macam modus operandi, dengan delih sebagai konsekuensi akibat tidak dilaksanakannya prestasi yang diperjanjikan.

4. Penipuan yang diatur dalam Pasal 378 KUHP, sebagaimana dijabarkan berikut. Pasal 378

"Barangsiapa dengan maksud untuk menguntungkan diri sendiri atau orang lain secara melawan hukum dengan memakai nama palsu atau martabat (hoedanigheid) palsu, dengan tipu muslihat, ataupun rangkaian kebohongan, menggerakan orang lain untuk menyerahkan barang sesuatu kepadanya, atau supaya memberi utang atau menghapuskan piutang, diancam karena penipuan, dengan pidana penjara paling lama empat tahun." 23

Pada kategori ini, sanksi kejahatan yang dikenakan murni mengenai penipuan, karena sedari awal tujuan jasa keuangan memberikan hutang adalah untuk menipu nasabah, yakni dengan cara klausul yang ada pada saat transaksi pinjam meminjam tidak dijalankan dengan semestinya pada saat transaksi sudah ditaken untuk dijalankan, atau dengan kata lain apa yang diperjanjikan tidak sama seperti yang dijalankan.

5. Fitnah, yang diatur dalam Pasal 311 ayat (1) KUHP sebagaimana dijabarkan berikut.

Pasal 311 ayat (1)

(1)Jika yang melakukan pencemaran atau pencemaran tertulis, dalam hal dibolehkan utuk membuktikan bahwa apa yang dituduhkan itu benar, tidak membuktikannya dan tuduhan dilakukan bertentangan dengan apa yang diketahui, maka dia diancam karena melakukan fitnah, dengan pidana penjara paling lama empat tahun. ${ }^{24}$

Pada kategori ini, fitnah dilakukan dengan cara seolah-olah pihak yang melakukan pinjaman tidak mampu membayar pinjamannya, dan menyebabkan pihak yang meminjam uang tidak dapat meminjam uang di platform lain karena dianggap tidak kompeten untuk menyelesaikan kewajibannya, padahal pinjaman sudah dilunasi sesuai tenggat waktu yang ditentukan.

\section{Penutup}

Berdasarkan penelitian yang dilakukan dapat disimpulkan bahwa terjadi pelanggaran yang dilakukan pemberi pinjaman kepada penerima pinjaman

\footnotetext{
${ }^{22}$ Ibid, Pasal 45 ayat (1).

${ }^{23}$ Op. Cit., Pasal 378.

${ }^{24}$ Ibid, Pasal 311 ayat (1).
} 
(nasabah), dan sanksi yang dijatuhkan hanya sebatas sanksi administratif dengan konsekuensi terparahnya yaitu pencabutan izin. Mengenai hal tersebut tentu saja tidak memberikan rasa keadilan terhadap nasabah, mengingat tindak kejahatan yang sudah dilakukan, oleh sebab itu peran hukum pidana sangat penting di sini, dengan cara menerapkan sanksi-sanksi yang berkaitan dengan kejahatan tersebut, seperti penyebaran data pribadi, pengancaman dalam penagihan, pelecehan seksual melalui media elektronik, penipuan dan fitnah.

Terkait permasalahan yang ada, penulis merekomendasikan agar pemerintah melalui lembaga pengawas keuangan (OJK) harus lebih ketat dalam mengawasi gerak-gerik jasa keuangan non Bank yang ada di Indonesia. Hal ini dapat dilakukan dengan menerapkan standar dan sanksi yang tinggi, yang tidak hanya berupa sanksi administratif melainkan juga pidana. Hal ini diharapkan agar dapat meminimalisir kejahatan melalui transaksi elektronik. Selain itu, diharapkan juga agar OJK sebagai lembaga yang berfungsi menyelenggarakan sistem pengaturan dan pengawasan terhadap seluruh kegiatan di dalam sektor jasa keuangan dapat membuat aturan yang mewajibkan perusahaan fintech peer to peer lending bekerja sama dengan perusahaan asuransi untuk mengurangi risiko kredit agar perlindungan hukum baik bagi pemberi pinjaman menjadidan penerima pinjaman lebih baik lagi.

\section{Daftar Pustaka}

\section{Buku}

Isretno Evita, Israhadi, Hukum Administrasi Negara (Pengantar Kajian Tentang Kewenangan dan Kebijakan Pemerintah), Cintya Press, Jakarta, 2006.

Kartika Elsi, Sari dan Advendi Simangunsong, Hukum Dalam Ekonomi, PT Gramedia Widiasarana, Jakarta 2007.Nurudin, Media Sosial Baru dan Munculnya Revolusi Proses Komunikasi, Buku Litera, Yogyakarta, 2012.

Rumondang Astri dkk, Fintech: Inovasi Sistem Keuangan Di Era Digital, Yayasan Kita Menulis, Medan, 2019.

S Gazalidan Rachmadi Usman, Djoni, Hukum Perbankan, Sinar Grafika, Jakarta, 2010.

\section{Jurnal}

Arif Syaifudin"Perlindungan Hukum Terhadap Para Pihak Didalam Layanan Financial Technologi Berbasis Peer to Peer (P2P) Lending", artikel dalam Dinamika Jurnal Ilmiah Ilmu Hukum, Vol. 26 Nomor 4, Februari, 2020.

Irma Muzdalifa, Inayah Aulia Rahma, dan Bela Gita Novalia, "Peran Fintech Dalam Meningkatkan Keuangan Inklusif Pada UMKM Di Indonesia (Pendekatan Keuangan Syariah)", artikel dalam Jurnal Masharif Al-Syariah : Jurnal Ekonomi dan Perbankan Syariah, Vol. 3, No. 1, 2018. 
Ratna Hartanto dan Juliani Purnama Ramli, "Hubungan Hukum Para Pihak Dalam Peer To Peer Lending", artikel dalam Jurnal Hukum IUS Quia Iustum Faculty Of Law UII, Vol. 25, Issue 2, Mei, 2018.

\section{Skripsi}

Asna Ridayani “Perlindungan Hukum Bagi Pengguna Jasa Peer To Peer Lending Terhadap Ketrerlambatan Pembayaran Pinjaman Dalam Finansial Teknologi", Skripi Fakultas Hukum Universitas Jember, 2019.

\section{Peraturan- Peraturan}

Undang-Undang Nomor 11 Tahun 2008 Tentang Informasi Dan Transaksi Elektronik.

Peraturan OJK Nomor 77/ POJK.01/ 2016 tentang Layanan Pinjam Meminjam Uang Berbasis Teknologi Informasi.

Otoritas Jasa Keuangan, Kajian Perlindungan Konsumen Sektor Jasa Keuangan: Perlindungan Konsumen Pada Fintech, Departemen Perlindungan Konsumen OJK,Jakarta, 2017.

\section{Website}

https:/ / www.cnbcindonesia.com/tech/20191014113024-37-106736/berkatfintech-lending-sederet-umkm-ini-bisa-naik-kelas, 